\title{
Analisis Brand Equity Pocari Sweat Dalam Persaingan Industri Minuman (Studi Kasus: Mahasiswa di Bogor)
}

\author{
Ferdie Pratama \\ Alumni Manajemen Fakultas Ekonomi dan Manajemen \\ Institut Pertanian Bogor \\ Jono M. Munandar \\ Dosen Manajemen fakultas Ekonomi dan Manajemen \\ Institut Pertanian Bogor \\ jonomun@gmail.com
}

\begin{abstract}
Isotonic drink is a new kind of product in Indonesian consumer goods. This kind of product entered Indonesian market in mid-80s. However, isotonic drink industry is growing up along with the increase of people's welfare and awareness of body health. One of isotonic drinks marketed in Indonesia is Pocari Sweat, produced by PT Amerta Indah Otsuka, which is the market leader in Indonesian isotonic drink industry. High level of competition put more burdens on the producer. PT Amerta has to ensure that Pocari Sweat get a strong position on consumers' minds. The objective of this research is to analyze Pocari Sweat's brand equity. It covers several elements: brand awareness, brand association, brand's perceived quality and brand loyalty. In order to see the overall competition among isotonic drinks, this research also involves several other brands such as ProSweat, Mizone, Aqua, and Coca-Cola. This research is conducted in three universities in Bogor; Bogor Institute of Agriculture (Institut Pertanian Bogor), Pakuan University and Ibnu Khaldun University. The result shows that in the element of brand awareness, Pocari Sweat is the most memorized brand. The association of brand image in brand association element shows that Pocari Sweat has two brand images: safe for health and fresh taste to kill thirst. Analysis on perceived quality with biplot method shows that Pocari Sweat has several attributive characteristics namely benefit, safe for health, eliminates dehydration and recharge stamina. Meanwhile, analysis in brand loyalty shows that Pocari Sweat doesn't have a strong brand loyalty yet.
\end{abstract}

Key words: Brand Equity, Brand Awareness, Brand Association, Perceived Quality, Brand Loyalty.

\section{Pendahuluan}

Perkembangan industri makanan dan minuman di Indonesia dalam beberapa tahun terakhir mengalami peningkatan. Hal ini dapat dikatakan wajar karena makanan dan minuman merupakan kebutuhan dasar yang diperlukan manusia sehari-hari. Industri minuman secara keseluruhan dibagi menjadi dua kelompok besar, yaitu minuman beralkohol dan non-alkohol. Dalam kelompok minuman non-alkohol, dibagi beberapa kelas lagi, yaitu minuman kesehatan (health drink), minuman ringan (soft drink), dan 
lain-lain. Untuk kelas minuman kesehatan dibagi menjadi beberapa jenis. Jenis yang terdapat pada minuman kesehatan antara lain isotonic drink, energy drink, dan milk fermentation.

Minuman isotonik yang masuk ke dalam kategori minuman tidak beralkohol sebenarnya merupakan salah satu barang baru dalam jajaran consumer goods di Indonesia. Produk ini baru masuk ke Indonesia pada pertengahan tahun 80-an. Namun, pasar minuman isotonik semakin berkembang seiring dengan semakin meningkatnya kesejahteraan dan tingkat kesadaran masyarakat terhadap kesehatan tubuh. Selama lima tahun terakhir tampak pasar minuman isotonik menunjukkan perkembangan yang cukup tinggi. Hal ini dapat dilihat dari semakin banyaknya produsen-produsen besar yang masuk ke dalam industri ini. Namun kendati hingga akhir tahun 2004 PT Amerta Indah Otsuka (AIO) yang merupakan produsen dan pemasar merek Pocari Sweat masih menjadi pemimpin pasar dalam industri minuman isotonik di Indonesia.

Penelitian ini fokus menganalisis merek Pocari Sweat dari elemen brand equity. Untuk melihat adanya tingkat persaingan, beberapa merek minuman dilibatkan dalam penelitian ini, yaitu merek ProSweat dan Mizone dari industri minuman isotonik, Aqua dari industri Air Minum Dalam Kemasan (AMDK), dan Coca-Cola dari industri minuman berkarbonasi.

\section{Metode Penelitian}

Penelitian ini dilaksanakan pada tiga Perguruan Tinggi yang ada di Wilayah Bogor yaitu, Institut Pertanian Bogor (IPB), Universitas Ibn Khaldun Bogor (UIKA), dan Universitas Pakuan (UNPAK). Metode yang digunakan dalam penelitian ini yaitu uji Cochran pada elemen Brand Association dan Semantic Differential, Analisis Biplot pada elemen Perceived Quality, skala Likert, rataan, dan simpangan baku pada elemen Brand Loyalty, serta analisis deskriptif pada elemen Brand Awareness.

\section{Hasil Penelitian}

\section{III.1. Karakteristik Responden}

Berdasarkan hasil penelitian yang dilakukan di lapangan, mayoritas responden berjenis kelamin perempuan sebanyak 113 orang $(56,5 \%)$ dan sebesar 87 orang $(43,5 \%)$ berjenis kelamin laki-laki. Berdasarkan usia, responden terbanyak berada pada usia 20 tahun (35,5\%), selanjutnya sebanyak 28,5\% responden berusia 21 tahun dan yang terkecil terdapat pada usia 25 tahun $(0,5 \%)$.

Berdasarkan total pengeluaran per bulan, responden terbanyak berada pada kelompok pengeluaran di bawah Rp500.000 (43\%) dan yang terkecil pada kelompok pengeluaran Rp800.001 - Rp900.000 (3,5\%). Berdasarkan total pengeluaran konsumsi per bulan, responden terbanyak berada pada kelompok pengeluaran Rp200.001 Rp300.000 (27,5\%), dan yang terkecil pada kelompok pengeluaran di atas Rp500.001 $(5,5 \%)$.

\section{III.2. Brand Awareness}

Berdasarkan survey terhadap 200 orang responden, sebagian besar (94\%) responden menyebutkan merek Pocari Sweat sebagai merek minuman isotonik yang paling diingat (top of mind). Sebanyak 132 orang responden (66\%) menyebutkan 
merek Mizone sebagai merek minuman isotonik kedua yang mereka ingat setelah menyebutkan merek pertama (brand recall).

Tingkatan selanjutnya adalah brand recognition, yaitu sebanyak 44 orang responden (22\%) perlu diingatkan akan keberadaan merek ProSweat, kemudian untuk merek Mizone 42 orang (21\%), sedangkan untuk merek Pocari Sweat hanya satu responden saja yang perlu diingatkan (0,5\%). Tingkatan terendah (unaware of brand) yaitu sebanyak 67 orang $(33,5 \%)$ tidak mengenal merek ProSweat, kemudian merek Mizone 16 orang $(8 \%)$ sedangkan untuk merek Pocari Sweat, tidak ada satu responden pun yang tidak mengenal merek tersebut.

\section{III.3. Brand Association}

Di dalam elemen brand association dilakukan pengujian asosiasi untuk melihat asosiasi mana yang menjadi brand image dari suatu merek. Asosiasi yang menjadi image merek Pocari Sweat yaitu: (1) aman bagi kesehatan dan (2) rasa yang segar pelepas dahaga. Asosiasi yang menjadi image merek Mizone yaitu: (1) kemasannya menarik, (2) aromanya enak, (3) aman bagi kesehatan, dan (4) rasa yang segar pelepas dahaga. Asosiasi yang menjadi image merek Aqua yaitu: (1) aman bagi kesehatan dan (2) harga yang murah. Asosiasi yang menjadi image merek Coca-Cola yaitu: (1) kemasannya menarik dan (2) aromanya enak. Merek ProSweat dari hasil pengujian tidak memiliki asosiasi yang dapat dijadikan image bagi merek tersebut.

\section{III.4. Perceived Quality}

Hasil pengujian dengan metode Semantic Differential menunjukkan bahwa merek Pocari Sweat dinilai konsumen lebih unggul pada atribut: (1) manfaat, (2) keamanan bagi kesehatan, (3) menghilangkan dehidrasi, (4) rasa, dan (5) memulihkan stamina. Merek Mizone dinilai konsumen lebih unggul pada atribut: (1) aroma, (2) kemasan, dan (3) banyaknya volume. Merek Aqua dinilai konsumen unggul pada atribut: (1) harga dan (2) kemudahan mendapat. Merek ProSweat dan Coca-Cola dinilai konsumen tidak memiliki keunggulan pada keseluruhan atribut dibandingkan dengan merek yang lainnya.

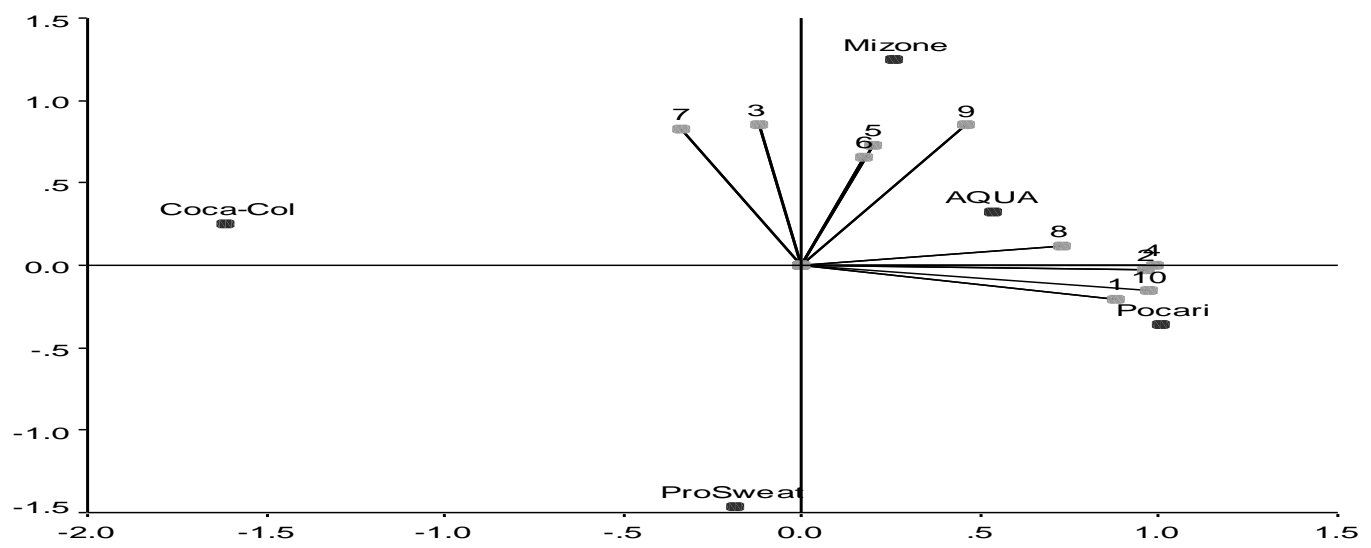

Gambar 1. Analisis Biplot untuk Atribut Merek-merek Minuman 
Keterangan :

Atribut 1 = Manfaat

Atribut 2 = Aman

Atribut $3=$ Aroma

Atribut 4 = Menghilangkan dehidrasi

Atribut $5=$ Harga
Atribut 6 = Kemudahaan mendapat

Atribut 7 = Kemasan

Atribut $8=$ Rasa

Atribut 9 = Volume $/$ isi

Atribut $10=$ Memulihkan stamina

Metode analisis biplot menunjukkan bahwa antarmerek memiliki posisi yang berbeda. Hanya merek Aqua dan Mizone yang posisinya berdekatan dan terletak pada kuadaran yang sama (Gambar 1). Kedekatan posisi antarmerek ini menggambarkan bahwa merek-merek tersebut memiliki karakteristik yang hampir sama. Analisis lain yang dapat diambil biplot yaitu tentang keragaman atribut. Semakin panjang garis suatu atribut, maka tingkat keragamannya semakin besar, begitu pula sebaliknya. Hasil penelitian menunjukkan bahwa masing-masing atribut hampir memiliki tingkat keragaman yang sama. Hal ini ditunjukkan dengan panjang garis masing-masing atribut yang tidak jauh berbeda.

Hubungan antar-atribut dapat dijelaskan pula melalui analisis ini. Korelasi positif terjadi antara atribut 2 (aman) dan atribut 4 (menghilangkan dehidrasi), antara atribut 5 (harga) dan atribut 6 (kemudahan mendapat), antara atribut 1 (manfaat) dan atribut 10 (memulihkan stamina), antara atribut 9 (volume/isi) dan atribut 8 (rasa), dan lainnya. Atribut yang memiliki korelasi positif dengan atribut yang lainnya dapat dijelaskan bahwa atribut tersebut akan mengalami perubahan jika atribut yang satunya berubah, begitu juga sebaliknya. Misalkan antara atribut 2 (aman) dan atribut 4 (menghilangkan dehidrasi), jika konsumen memandang bahwa produk tersebut tidak menghilangkan dehidrasi, maka konsumen juga akan memandang bahwa produk tersebut tidak aman bagi kesehatan.

Informasi terakhir yang dapat diperoleh dari metode analisis ini yaitu nilai peubah (atribut) pada suatu objek (merek). Suatu karakteristik merek, dapat disimpulkan melalui kedekatan posisi relatifnya dengan suatu atribut. Dari Gambar 1 terlihat bahwa posisi relatif merek Pocari Sweat dekat dengan atribut 1 (manfaat), atribut 2 (aman), atribut 4 (menghilangkan dehidrasi), dan atribut 10 (memulihkan stamina). Hal ini menggambarkan bahwa Pocari Sweat memiliki karakteristik dari keempat atribut tersebut. Keempat atribut tersebut dapat dikelompokkan kepada atribut yang berkaitan dengan aspek kesehatan. Merek Mizone dekat posisinya dengan atribut 5 (harga), atribut 6 (kemudahan mendapat), dan atribut 9 (volume/isi). Ketiga atribut tersebut merupakan keunggulan dari merek Mizone, dengan harga jual yang murah dibandingkan dengan produk minuman isotonik yang lain namun memiliki volume yang banyak, maka kedua atribut tersebut melekat pada merek Mizone. Keunggulan lainnya yaitu dengan memanfaatkan saluran distribusi dari produsen Aqua, maka merek Mizone mudah diperoleh di mana saja. Ketiga atribut yang melekat pada merek Mizone juga melekat pada merek Aqua, namun terdapat satu atribut lagi yang melekat pada merek Aqua, yaitu atribut 8 (rasa). Atribut ini melekat kepada merek Aqua, karena merek ini dipandang sebagai minuman yang dapat memberikan rasa segar pelepas dahaga. Atribut 3 (aroma) dan atribut 7 (kemasan) terletak pada Kuadran yang sama dengan merek Coca-Cola, namun posisi atributnya masih jauh dengan posisi 
relatif merek Coca-Cola. Merek ProSweat yang terletak pada Kuadran III, tidak memiliki kedekatan dengan atribut apa pun, karena tidak ada satu atribut pun yang berada pada Kuadran III.

\section{III.5. Brand Loyalty}

Dalam penelitian ini, analisis brand loyalty dilakukan untuk mengetahui loyalitas dari pelanggan minuman isotonik merek Pocari Sweat yang melibatkan 144 responden. Pada elemen brand loyalty terdapat lima tingkatan dari mulai yang terendah sampai dengan yang tertinggi yaitu, switcher, habitual buyer, satisfied buyer, liking the brand, dan committed buyer. Pada tingkatan switcher, sebesar 6,94\% pelanggan merek Pocari Sweat akan berpindah merek minuman dikarenakan faktor harga. Pada tingkatan habitual buyer, sebesar 20,14\% pelanggan merek Pocari Sweat membeli minuman tersebut dikarenakan faktor kebiasaan. Pada tingkatan satisfied buyer, sebesar $63,19 \%$ pelanggan merek Pocari Sweat merasakan kepuasan dalam mengonsumsi minuman tersebut. Pada tingkatan liking the brand, sebesar $61,81 \%$ pelanggan merek Pocari Sweat menyukai merek minuman isotonik tersebut. Pada tingkatan tertinggi yaitu committed buyer, sebesar 7,64\% pelanggan merek Pocari Sweat merupakan pelanggan yang memiliki komitmen tinggi dengan mempromosikan dan merekomendasikan minuman ini kepada pihak lain.

Suatu bentuk piramida brand loyalty yang terbalik akan menggambarkan bahwa merek tersebut memiliki brand loyalty yang kuat. Piramida brand loyalty merek Pocari Sweat (Gambar 2) belum membentuk piramida yang terbalik karena terdapat penyempitan pada tingkatan liking the brand dan committed buyer. Dapat disimpulkan bahwa merek Pocari Sweat belum memiliki brand loyalty yang kuat.

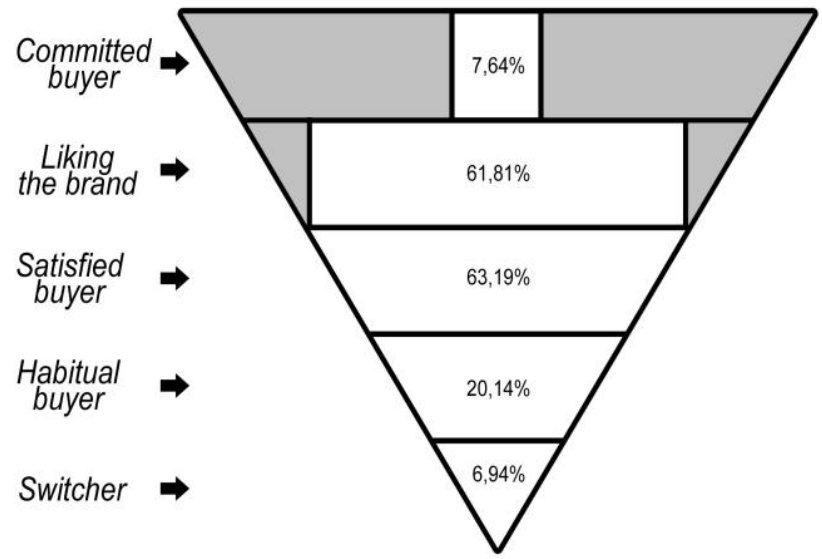

Gambar 2. Piramida Brand Loyalty Minuman Isotonik Merek Pocari Sweat

\section{Kesimpulan}

Di dalam elemen brand awareness, merek Pocari Sweat memiliki posisi tertinggi pada tingkatan top of mind. Sedangkan pada brand recall posisi tertinggi ditempati oleh merek Mizone. Asosiasi yang membentuk brand image merek Pocari Sweat yaitu aman bagi kesehatan dan rasa yang segar pelepas dahaga. Merek Mizone mendapatkan empat brand image, yaitu kemasannya menarik, aromanya enak, aman 
bagi kesehatan, dan rasa yang segar pelepas dahaga. Sedangkan merek ProSweat tidak memiliki asosiasi yang dapat menjadi brand image.

Pada elemen perceived quality, konsumen menilai bahwa merek Pocari Sweat memiliki keunggulan yang lebih banyak dibandingkan merek lainnya, yaitu dari atribut manfaat, aman bagi kesehatan, menghilangkan dehidrasi, rasa, dan memulihkan stamina. Keunggulan dari atribut aroma, kemasan, dan volume diraih oleh merek Mizone. Sedangkan Aqua dipandang oleh konsumen memiliki keunggulan dari atribut harga dan kemudahan mendapat.

Merek Pocari Sweat memiliki karakteristik dari atribut manfaat, aman bagi kesehatan, menghilangkan dehidrasi, dan memulihkan stamina yang tercermin dari kedekatan antara posisi relatif merek dengan atribut. Brand loyalty merek Pocari Sweat memiliki nilai 6,94 persen pada tingkatan switcher. Tingkatan habitual buyer memliki nilai sebesar 20,14 persen, tingkatan satisfied buyer memiliki nilai sebesar 63,19 persen, tingkatan liking the brand memiliki nilai sebesar 61,81 persen, dan yang terakhir tingkatan committed buyer memiliki nilai 7,64 persen. Sementara itu, bentuk piramida brand loyalty Pocari Sweat belum memperlihatkan bentuk piramida terbalik yang menunjukkan bahwa brand loyalty Pocari Sweat belum kuat.

\section{Daftar Pustaka}

Aaker, D. 1997. Manajemen Ekuitas Merek: Memanfaatkan Nilai dari Suatu Merek. Mitra Utama, Jakarta.

Diah, M. 2005. Analisis Ekuitas Merek Kartu Pra Bayar IM3 SMART berdasarkan Persepsi Mahasiswa. Skripsi pada Departemen Manajemen, Fakultas Ekonomi, Universitas Indonesia.

Kotler, P. 2002. Manajemen Pemasaran (Terjemahan, Jilid 2). PT. Prenhallindo, Jakarta.

Mantoroadi, B.L. 2004. Analisis Ekuitas Merek Bumbu Kaldu Royco di Kota Bogor. Tesis pada Program Studi Magister Manajemen Agribisnis, Sekolah Pasca Sarjana, Institut Pertanian Bogor.

Planning and Analysis Division PT Amerta Indah Otsuka. 2004. Gambaran Bisnis Industri Minuman Dalam Kemasan Indonesia 2000-2004 dan Prospek Bisnis 2005-2009.

Sugiyono. 2003. Statistika untuk Penelitian. Alfabeta. Bandung

Supranto, J. 2001. Pengukuran Tingkat Kepuasan Pelanggan Untuk Meningkatkan Pangsa Pasar. Rineka Cipta. Jakarta

Umar, H. 2003. Riset Sumber Daya Manusia. PT. Gramedia Pustaka Utama, Jakarta.

UU No. 15 Tahun 2001. http://www.dgip.go.id/article/archive18. [27 September 2005] 